\title{
Robotic-assisted endoscopic full-thickness resection of a gastrointestinal stromal tumor: the tip of the iceberg
}

A 56-year-old woman presented for evaluation of a gastric body submucosal nodule. She underwent endoscopic ultrasound, which revealed a hypoechoic lesion arising from the muscularis propria that measured $21.8 \times 17.9 \mathrm{~mm}$ in diameter. Fine-needle aspiration demonstrated spindle cells positive for C-KIT and DOG1 , consistent with gastrointestinal stromal tumor (GIST).

For management of the lesion, she elected to undergo an endoscopic full-thickness resection (EFTR). The borders of the

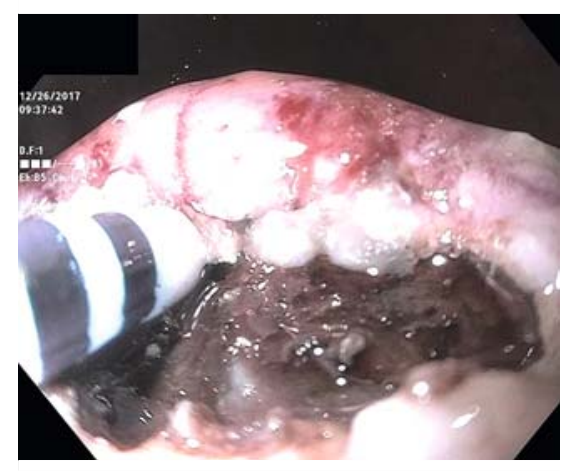

- Fig. 1 Accessing the submucosal space for endoscopic full-thickness resection.

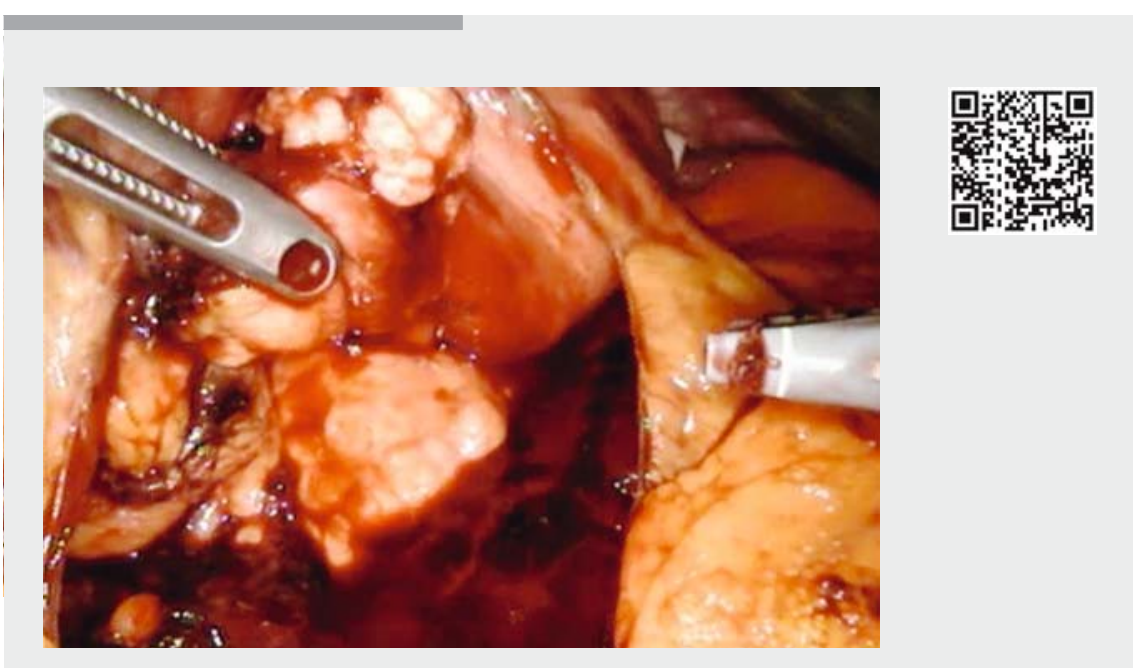

Video 1 Robotic-assisted endoscopic full-thickness resection with inversion of lesion into the stomach for removal. lesion were marked circumferentially. After injection to create a submucosal space, the mucosa was incised using a hybrid knife. The submucosa was exposed to identify the lesion. EFTR was performed after the lesion was fully exposed ( $\mathbf{F i g . 1 , ~} \mathbf{1}$ Video $\mathbf{1}$ ). As dissection continued, multiple large blood vessels were seen encasing the lesion. There was significant bleeding, which was controlled using coagulation grasper forceps and hemostatic clips. Although hemostasis was achieved, a decision was made to complete the procedure via surgical resection given the multiple blood vessels encasing the lesion.

The procedure was converted to a robotic-assisted EFTR ( $\triangleright$ Video 1 ). The lesion was identified via robotic exposure. The GIST and previously placed clips were excised with the aid of upper endoscopy and a vessel sealer. The lesion was placed in the stomach, removed endoscopically, and the gastric defect was closed. The final lesion measured $4.5 \times 3.2 \mathrm{~cm}$, which was larger than the size predicted initially by endosonography.
EFTR has been described for management of subepithelial gastric tumors [1, 2]. Bleeding during resection has been reported in up to $38.7 \%$ of cases [3]. Endoscopic hemostasis is typically successful. However, gastroenterologists who undertake EFTR must always be prepared for complicated procedures, which occasionally require conversion to surgical resection. Laparoscopy has been previously demonstrated to assist EFTR [4]. We demonstrate a successful case of robotic-assisted EFTR of a GIST.

Endoscopy_UCTN_Code_CPL_1AH_2AZ

Competing interests

Michel Kahaleh MD has received grant support from Boston Scientific, Fujinon, EMcison, Xlumena Inc., W.L. Gore, MaunaKea, Apollo Endosurgery, Cook Endoscopy, ASPIRE Bariatrics, GI Dynamics, NinePoint Medical, Merit Medical, Olympus and MI Tech. He is a consultant for Boston Scientific, Xlumena Inc., Concordia Laboratories Inc, ABBvie, and MaunaKea Tech.

All other authors have no conflicts of interest to report.

The authors

Monica Saumoy ${ }^{1}$, Brandon Guenthart ${ }^{1}$, Luai Madanat $^{2}$, Cheguevara Afaneh ${ }^{2}$, Michel Kahaleh $^{3}$

1 Department of Gastroenterology, Weill Cornell Medicine, New York Presbyterian Hospital, New York, United States

2 Department of Surgery, Weill Cornell Medicine, New York Presbyterian Hospital, New York, United States

3 Department of Gastroenterology, Robert Wood Johnson Medical Center, New Brunswick, United States 
Michel Kahaleh, MD, AGAF, FACG, FASGE

Department of Medicine, Rutgers Robert

Wood Johnson Medical School Rutgers, The

State University of New Jersey Robert Wood

Johnson University Hospital, 1 RWJ Place,

MEB 464, New Brunswick, NJ 08901, United

States

Phone: +1 732-235-7784

mkahaleh@gmail.com

\section{References}

[1] Zhou PH, Yao LQ, Qin XY et al. Endoscopic full-thickness resection without laparoscopic assistance for gastric submucosal tumors originated from the muscularis propria. Surg Endosc 2011; 9: 2926-2931
[2] Cai M, Zhou P, Lourenco LC et al. Endoscopic full-thickness resection for gastrointestinal subepithelial tumors. Gastrointest Endosc Clin N Am 2016; 26: 283-295

[3] Schmidt A, Bauder M, Riecken B et al. Endoscopic full-thickness resection of gastric subepithelial tumors: a single-center series. Endoscopy 2015; 47: $154-158$

[4] Lim SG, Hur H, Han SU et al. Laparoscopyassisted endoscopic full thickness resection for gastric subepithelial tumors originated from the musuclaris propria layer: a pilot study with literature review. Scand J Gastroenterol 2017; 52: 257-263

\section{Bibliography}

DOI https://doi.org/10.1055/a-0624-1644

Published online: 12.6.2018

Endoscopy 2018; 50: E216-E217

(c) Georg Thieme Verlag KG

Stuttgart · New York

ISSN 0013-726X

\section{ENDOSCOPY E-VIDEOS}

https:/|eref.thieme.de/e-videos

口回 Endoscopy E-Videos is a free Fection, reporting 回舴: on interesting cases and new techniques in gastroenterological endoscopy. All papers include a high quality video and all contributions are freely accessible online.

This section has its own submission website at

https://mc.manuscriptcentral.com/e-videos 